\title{
Sarcoptic Mange Infestation in Sheep with Its Therapeutic Management
}

\author{
Dipali Parmar* and Dinesh Chandra \\ Division of Parasitology, Indian Veterinary Research Institute, Izatnagar-243122, \\ Uttar Pradesh, India \\ *Corresponding author
}

\begin{abstract}
A B S T R A C T
Sarcoptic mange infestation is a rare condition in sheep, but when the disease occur it leads to development of severe pruritic lesions mostly on non-wooly regions of the body.

Keywords

Sheep, Sarcoptic mange, Ivermectin

Article Info

Accepted: 06 September 2018 Available Online: 10 October 2018 Incidence of disease is most common among animals reared under intensive rearing system. Being contagious in nature, it affects the entire herd at a given time. Overcrowding along with poor managemental condition predispose the animal to disease development and parasite establishment. In the present study eighteen non-descript sheep $(n=18)$, naturally acquired mite infestation during peak winter season with the development of mange lesion around lips, nostrils and muzzle area. Microscopic examination of deep skin scraping from affected animals revealed the presence of sarcoptes mite that was identified morphologically. All animals were treated with Inj. Ivermectin @ $200 \mathrm{mcg} / \mathrm{kg}$ body weight sub cutaneous $(\mathrm{S} / \mathrm{C})$ at weekly interval along with topical application and supportive therapy. Improvement in animal condition was observed from 10 days post treatment with full recovery within 20-25 days. Supportive therapy along with topical application of ointment was helpful in fast healing of mange lesions.
\end{abstract}

\section{Introduction}

Mange is a collective term given to skin disease caused due to parasitic mites that affects wide variety of domestic as well as wild animals (Nwoha, 2011). These parasitic mites feed on the lymph, blood, tissue and skin of the animals; there by releasing certain substances that cause further skin damage (Tolossa, 2014). In sheep, sarcoptic mange commonly known as head mange is a rare condition; however infestation with Sarcoptes scabies var. ovis mite occurs occasionally. Affected sheep shows intense pruritus with rubbing and scratching of the body against trees and walls (Soulsby, 1982). Because of severe itch, sheep are restless and are unable to feed and graze, leading to progressive emaciation (Taylor et al., 2007). S. scabiei, the causative agent is usually having number of varieties, each being specific to a particular host species (Radostits et al., 2007). Few reports are available on sarcoptic mange infestation in sheep from India. Khan et al., 1999 reported incidence rate of 21.10 $22.05 \%$ with sarcoptic mange in sheep flocks at ICAR-Central Sheep and Wool Research Institute, Avikanagar, Rajasthan. Other reports from Vyas et al., (2002) and Sawale et al., (2012), showed increased rate of up to 32.00 
and $46.66 \%$ in sheep at Bikaner and Mumbai, respectively. Mange mites cause severe economic losses to tanning industry by reducing quality of skin and hides, they spend their entire lifecycle on the host animal thereby ingesting and puncturing skin surface leading to small, epidermal lesions (Lefevre et al., 2010). Female parasites leads to tunnel formation in the epidermis, whereby they deposit eggs causing marked irritation by tissue injury, hence leading to hyperkeratinisation (Sloss, 1994). The entire life cycle is completed in about 10-13 days (Radostits et al., 2007).

Non wooly areas and thin skinned areas of the body are mostly affected showing alopecia, skin thickening and crust formation (Sloss, 1994). Various risk factors are associated with the development of mange infestation in animals which include poor managemental conditions, age, sex and climatic conditions. Animals with poor, emaciated body condition and those residing in overcrowded environment are most susceptible. The disease occurrence is more common in cold and wet climatic conditions adding in easy dispersal and spread of mite within the herd. Lower incidence rate of mange is seen during peak summer season (Radostits et al., 2007). Higher prevalence rate of $(82.14 \%)$ is present in animals reared on semi intensive systems when compared to intensively reared animal systems (Murthy et al., 2013).

One of the best methods to control mange in animal is by the use of Ivermectin along with other sprays on shed and on animal. Ivermectin is a broad-spectrum anti-parasite drug derived from soil bacterium Streptomyces avermitilis. It can be used as both endoparasitic and ectoparasitic medication. It binds selectively and with high affinity to glutamate-gated chloride ion channels in invertebrate muscles which lead to increase in permeability of the cell membrane to chloride ions thus causing hyperpolarization, leading to paralysis and death of the parasite. Use of ivermectin for treatment of sarcoptes mites was evaluated by various workers (Desoky, 2011 and Witmer et al., 1995) in which they used drug twice in a month schedule. These results obtained were better when compared to one time dose.

All the animals showed a slight improvement in the clinical picture of mange disease by using Ivermectin injection, with recovery of skin within 20- 30 days. Avermectin injection at the recommended dose controlled reinfection with sarcoptic mange.

\section{Case history and observations}

Eighteen non-descript sheep $(n=18)$, naturally acquired mite infestation during peak winter season with development of mange like lesions around lips, nose, neck regions. Affected sheep showed intense itching with rubbing of body against the walls and wool plucking.

Disease spread was rapid and affected almost all animals in the herd. Severely infested sheep showed crusty lesions around lips and nostrils; focal hair loss around neck and ear regions was observed. Animals were restless with poor body condition and alopecia.

Deep skin scrapings using scalpel moistened with glycerine were collected from lesions around lips, nose, ears and face in $10 \%$ $\mathrm{NaOH}$. Scrapings were processed in laboratory, skin debris was removed and all the scrapings were examined under microscope for the presence of parasitic mites. After confirming presence of mites microscopically and by correlating clinical and laboratory findings all animals were treated with Inj. Ivermectin (1\% IvermectinNeomec $^{\circledR}$, Intas, Access Pharmaceuticals Pvt. Ltd, Ahmedabad, India) @ $200 \mathrm{mcg} / \mathrm{kg}$ body 
weight sub cutaneous (S/C) at weekly interval along with topical application. Total of two injections of Ivermectin at weekly intervals were given to the sheep. Topical application with ointment Lorexane ${ }^{\circledR}$ (Virbac, India) alond with Mineral and vitamin supplementation (Tribivet $^{\circledR}$, Intas, Insat Pharma, Uttarakhand, India) was done to enable improvement in body condition of animals. Blood was collected aseptically in vacutainers for estimation of Haemoglobin and packed cell volume count before and after treatment.

\section{Results and Discussion}

Examination of animals showed presence of mange lesions initially on eyes, nostrils which further spread to areas behind ears (Fig. 1). Clinical signs of intense itching with sheep rubbing its body against wall were observable. Affected sheep had reduced feed intake with development of crusty lesions. Wool became loose and fell in patches leading to focal naked areas on animal body. Widespread wool loss was observed on the animal body around affected areas. Lesions grow slowly and affected adjacent areas. Microscopic examination of deep skin scrapings revealed presence of Sarcoptes mites (Fig. 2) which could be differentiated based on morphological characters for presence of short legs, unsegmented pedicels, terminal anus (Soulsby, 1982).

Following treatment with Inj. Ivermectin @ $200 \mathrm{mcg} / \mathrm{kg}$ sub cutaneous (S/C) at weekly interval; slight recovery was observable by 15 days post treatment. Improvement in condition of animal with gradual disappearance of crusty lesion, scabs and wrinkles was seen. Appearance of fresh new skin with hairs was noticed by $20-25^{\text {th }}$ day post treatment in all the affected sheep.

The present findings are in agreement with the findings of Hengge et al., (2006); Akomas et al., (2011), Murthy et al., (2013), Soundararajan et al., (2016). Overall appearance of animals improved following treatment with Ivermectin. This finding is in agreement with (Alasaad et al., 2011 and Desoky, 2011).

Improvement in haemoglobin and PCV count was observed. Haemoglobin and PCV increased from initial value of $8.48 \pm 0.21$ and $23.72 \pm 0.66$ to $11.14 \pm 0.28$ and $29.55 \pm 0.92$, respectively.

Fig.1 Grossly visible mange lesions on head region of the affected animals, around muzzle and eye area
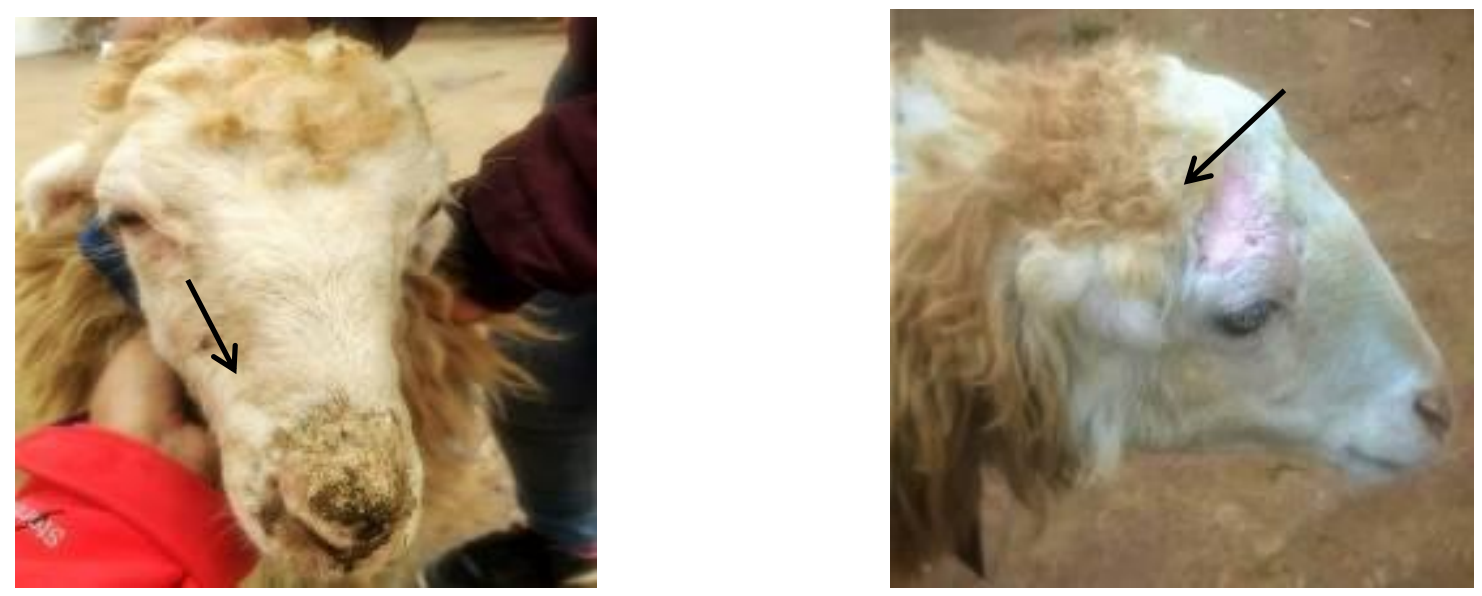
Fig.2 Microscopic examination of deep skin scrapping under 10x and 40x showing presence of Sarcoptes spp. mange mite

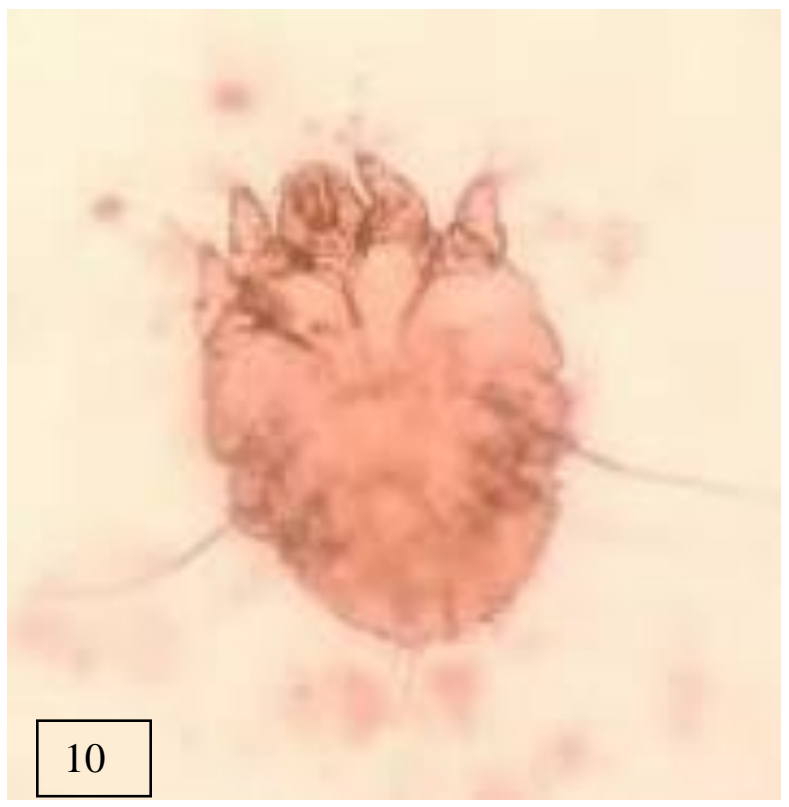

Although sarcoptic mange infestation in sheep is not a deadly disease however, it affects overall health status of the affected animal. Moreover disease is contagious in nature spreading quickly among herd. Treatment with Ivermectin $\left(\mathrm{Neomec}^{\mathrm{B}}\right)$ was useful with complete elimination of parasitic mite by day 25. Ivermectin is a group of drug in class Abermectins that have good efficacy against both endoparasites and ectoparasites. Hence treatment with Ivermectin can be beneficial under field conditions against various parasitic infestations, thereby, saving economy of farmers.

\section{References}

Akomas, S. C., Obijuru, O. C., and Herbert, U. 2011. Hematologic and serologic changes following ivermectin treatment in mange infested West African Dwarf goats. Advances in Environmental Biology. Pp. 2557-2561.

Alasaad, S., Walton, S., Rossi, L., Bornstein, S., Abu-Madi, M., Soriguer, R, C., Fitzgerald, S., Zhu, X, Q.,

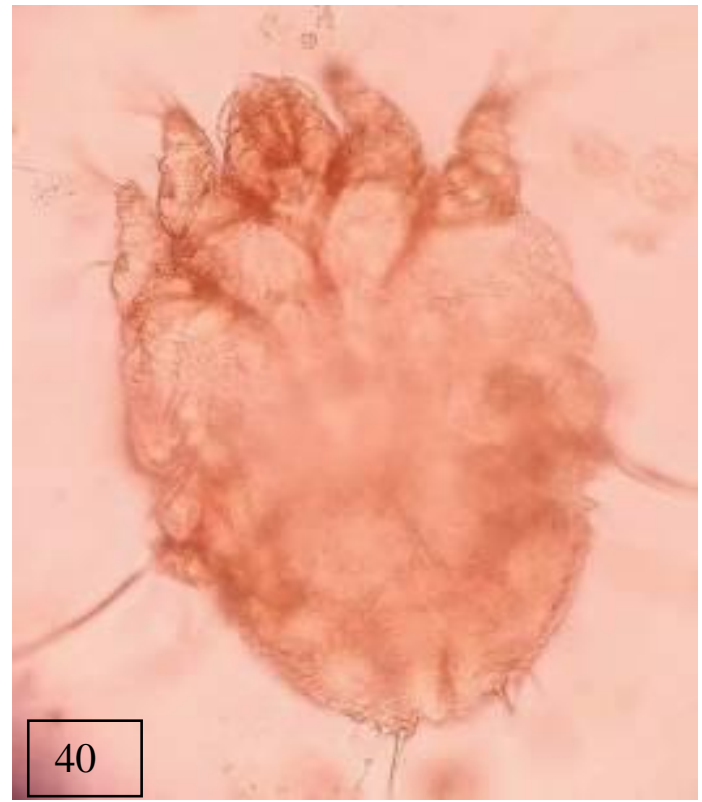

Zimmermann, W., Ugbomoiko, U, S., and Pei, K. J. C. 2011. Sarcoptes-world molecular network (Sarcoptes-WMN): integrating research on scabies. International Journal of Infectious Diseases. 15(5): 294-297.

Desoky, A, S, S. 2011. Studies on certain ectoparasites associated with some farm animals and their control (Doctoral dissertation, Ph. D. Thesis, Fac Agric Assiut Univ., Assiut, Egypt).

Hengge, U, R., Currie, B, J., Jäger, G., Lupi, O., and Schwartz, R, A. 2006. Scabies: a ubiquitous neglected skin disease. The Lancet infectious diseases. 6(12): 769779.

Khan, F, A., Swarnkar, C, P., Singh, D., and Bhagwan, P, S, K. 1999. Efficacy of closantel against sarcoptic mange in sheep. Indian Veterinary Journal. 76(9): 788-790.

Lefèvre, P, C., Blancou, J., Chermette, R., and Uilenberg, G. 2010. Infectious and Parasitic Diseases of Livestock: General considerations, viral diseases, Bacterial 
diseases, fungal diseases, parasitic diseases. Vol. 2 Tec. \& doc.

Murthy, G, S, S., Nagesha, A, M., and Gowda, K, H. 2013. Therapeutic management of sarcoptic mange in a sheep flock. Journal of parasitic diseases. 37(2): 281-282.

Nwoha, R, I, O. 2011. A case report on scabies in a goat. Clinical Reviews and Opinions. 3(5): 51-54.

Radostitis, A, M., Gay, C, C., Blood, D, C., and Hincheliff, K, W. 2007. Veterinary Medicine: A Textbook of the Diseases of Cattle, Sheep, Pigs, Goats and Horses. $10^{\text {th }}$ edn, W. B. Saunders, London, U.K. Pp. 1608-1609.

Sawale, G, K., Bharkad, G, P., Ghorpade, P, P., and Moregaonkar, S, D. 2012. Sarcoptic mange infestation in Bunner sheep flock: Case report. Journal of Veterinary Parasitology. 26(2): 189190.

Sloss, M, W. 1994. Veterinary clinical parasitology. Low state press, Black wall Publishing Company. Pp. 121-127.
Soulsby, E, J, L. 1982. Helminths, arthropods and protozoa of domesticated animals (No. Ed. 7). Bailliere Tindall.

Soundararajan, C., Nagarajan, K., Raja, A, A., and Prakash, M, A. 2016. Incidence of Sarcoptic Mange and Its Control with Ivermectin in Sheep.

Taylor, M, A., Coop, R, L., Wall, R, L. 2007. Veterinary Parasitology. Third ed., Blackwell Publishing. Pp. 159-161.

Tolossa, Y, H. 2014. Ectoparasitism: Threat to Ethiopian small ruminant population and tanning industry. Journal of Veterinary Medicine and Animal Health. 6(1): 25-33.

Vyas, G, B., Gauri, A, A., Murdia, C, K., and Purohit, N. 2002. Mange in sheep - A trial report. Veterinary Practitioner. 3:53.

Witmer, G, W., Fall, M, W., Fiedler, L, A. 1995. Rodent control, research needs, and technology transfer. In International wildlife management congress. Pp. 1626.

\section{How to cite this article:}

Dipali Parmar and Dinesh Chandra. 2018. Sarcoptic Mange Infestation in Sheep with Its Therapeutic Management. Int.J.Curr.Microbiol.App.Sci. 7(10): 845-849.

doi: https://doi.org/10.20546/ijcmas.2018.710.093 